\title{
Knowledge and Attitudes of Patients about Dental Implants as a Treatment Option after Tooth Extraction
}

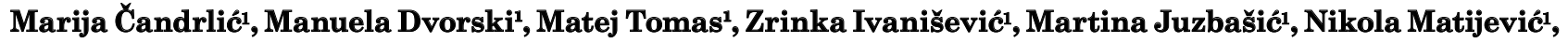 \\ Đorđe Petrovićé ${ }^{\text {, Marko Matijević }}{ }^{1}$
}

${ }^{1}$ Faculty of Dental Medicine and Health, Josip Juraj Strossmayer University of Osijek, Osijek, Croatia

${ }^{2}$ Dentistry Clinic of Vojvodina, Novi Sad, Serbia

\begin{abstract}
A B S T R A C T
The aim of the study is to determine patients' knowledge and attitudes toward dental implants as a therapeutic option after tooth extraction and to examine the sources of information about dental implants and determine the most common barriers in deciding for this type of therapy. The cross-sectional study included 130 patients. An anonymous survey questionnaire was used to conduct the research. The survey questionnaire consists of a total of 17 multiple-choice questions. Respondents showed good knowledge of dental implants except for knowledge of dental implant duration where subjects mostly stated that a dental implant lasts a lifetime. For most respondents, the dentist is the main source of information related to dental implants. The cost of the procedure for most respondents is a major barrier in decision to install a dental implant, but most of them want to know more about dental implants. Statistically significant differences were observed in patients 'knowledge in relation to age and level of education and patients' attitudes in relation to gender, age, and level of education.
\end{abstract}

Key words: dental implant, treatment modality, knowledge, missing teeth

\section{Introduction}

Dental health greatly affects the well-being and quality of life of each individual. Healthy teeth complete a person's appearance and enable proper nutrition. Loss of one or more natural teeth often results in several deficiencies, such as difficulty in speaking and feeding. Also, loss of self-confidence and reduced social interactions due to discomfort caused by lack of teeth or wearing dentures are not excluded ${ }^{1}$. The main task of prosthetics is the rehabilitation of patients after tooth loss and the establishment of a stable function of the stomatognathic system. With the progress of dental implantology, dental implants are increasingly coming into focus as the highest quality and longest-lasting solution in the rehabilitation of partially or completely toothless patients. The advantage of dental implants, over traditional prosthetic methods, is that dental implants provide satisfactory retention of prosthetic work and do not require additional grinding of adjacent teeth to compensate for the lost tooth ${ }^{1}$. A dental implant is the best choice for tooth replacement because it lasts 15 to 20 years and has a high success rate ${ }^{2}$. Despite the benefits of dental implants, the difference between need and demand is still large. It is assumed that such a difference occurs due to lack of information and lack of awareness within the dental patient population, but also due to financial factors ${ }^{1}$.

It is known that tooth loss occurs with aging. Various studies have shown that the loss of the teeth of the upper jaw and then the lower jaw is more common. It has also been observed that posterior teeth are lost before anterior $t^{t e e t h}{ }^{3}$. Tooth deficiency impairs the integrity of the dentition and intermaxillary relationship leading to biostatic imbalance and causing impairment of the stomatognathic system ${ }^{4}$.

Today, aesthetics are more important to patients than dental function. They find it uncomfortable to be without front teeth and consequently revive the discomfort in everyday social contacts. Restoring facial aesthetics can be

Received for publication April 10, 2021 
a challenge and is a major factor in making decisions about the type of prosthetic procedures to be performed on a patient.

In the late $1950 \mathrm{~s}$, the first screw-shaped titanium implant was made in Sweden by anatomist P. I. Branemark. During this period, the first introduction of intraoral application of dental implants by osseointegration as it is known today occurs ${ }^{5,6}$. Originally, dental implants were used to treat completely or partially edentulous patients ${ }^{5}$. Over time, they have proven to be very high quality and long-lasting solution for replacing natural teeth. Studies have shown that $89 \%$ of patients wear a dental implant more than 10 years after its placement. The introduction of a dental implant in place of a prosthesis carrier has led to great development and progress in reconstructive dental therapy ${ }^{7}$. In addition to not requiring additional grinding of adjacent teeth to compensate for a lost tooth, dental implants also provide good function, efficacy, stability, and provide support to dentures ${ }^{1,5}$. By influencing all of these functions, dental implants can greatly improve quality of life and aid in rehabilitation in partially or completely edentulous patients and are today considered the gold standard in replacing a lost tooth ${ }^{5,8}$. Given all the benefits of a dental implant, there are many indications for its use, such as the edentulous upper or lower jaw, partial edentulousness, and lack of only one tooth ${ }^{6,9}$. It is important to mention that the first and most important step in preparing dental implant therapy is to make a thorough and detailed history, which includes assessing social and economic status, general health, and taking medical and dental history, and examining harmful habits ${ }^{7}$. Also, before the start of therapy, complete rehabilitation of the oral cavity is required, which includes the repair of caries, removal of plaque and tartar, treatment of periodontal pockets, inflammation, and the like ${ }^{6}$. Patient understanding, cooperation, and expectations are very important for initiating successful treatment ${ }^{7}$.

The aim of this study was to examine patients' knowledge and attitudes about dental implants as a therapeutic option after tooth extraction and to examine the sources of information about dental implants and determine the most common barriers in decision making for this type of therapy.

\section{Participants and methods}

\section{Participants}

The cross-sectional study included patients in the dental offices of the Health Center in Osijek. A total of 130 patients who agreed to complete the questionnaire at the time of the study were included in the study. Respondents were asked to fill in the questionnaire on their own, and before completing the questionnaire, the purpose of the study was explained to them. Respondents were provided with data confidentiality and the opportunity to withdraw from the study at any time. The research was approved by the Ethics Committee of the Osijek Health Center. The survey was conducted during April and May 2019.

\section{Questionnaire procedures}

The survey questionnaire consists of a total of 17 questions to which multiple answers were offered. The first part of the questionnaire, ie. the first 5 questions, refers to general data on respondents: age, gender, place of residence, level of education, and financial status. The remaining questions, 12 of them, relate to patients 'knowledge and attitudes about dental implants. Respondents answered if they were missing any teeth. Their position on the importance of tooth extraction, their information on available treatments, and general knowledge and sources of information on dental implants were examined. Also, their knowledge about the location of placement, the material from which they are made, the lifespan and hygiene of the dental implant were examined. Finally, their most important factor in deciding on dental implant therapy, who implants them, and interest in expanding their knowledge of dental implants were examined.

\section{Data collection and statistical analysis}

Category data are presented in absolute and relative frequencies. Numerical data are described by the median and limits of the interquartile range. Differences of categorical variables were tested by $\mathrm{X}^{2}$ test. The normality of the distribution of numerical variables was tested by the Kolmogorov-Smirnov test. All $p$ values are two-sided. The significance level was set to $\alpha=0.05$. The statistical program SPSS (version 24.0, SPSS Inc., Chicago, IL, USA) was used for statistical analysis ${ }^{10}$.

\section{Results}

130 respondents participated in the study, of which 53 (41\%) were men and 77 (59\%) were women. The median age is 39 years (interquartile range of 29 to 51) ranging from 18 to 78 years. The majority of respondents live in the city (79\%), most of them stated that they have a high school diploma (52\%) and describe their financial status as good (60\%). Most respondents report missing at least one tooth (72\%) (Table 1).

When we talk about the knowledge of respondents about dental implants, most of the state (61\%) that the replacement of extracted teeth is very important, implants are placed in the bone of thought also most respondents (74\%), $40 \%$ of them think they are built of titanium and that $39 \%$ of respondents (74\%) believe that implants require the same care as natural teeth and $75 \%$ of respondents say that oral surgeons are the best trained to place implants (Table 2).

The majority of respondents in our study, 77 of them (59\%), state that the cost of the procedure is their most important factor when deciding on the installation of a dental implant, $82 \%$ of respondents are familiar with the 
TABLE 1

DEMOGRAPHIC DATA OF THE SUBJECTS

\begin{tabular}{llc}
\hline Variable & male & $\begin{array}{c}\text { Number of } \\
\text { subjects (\%) }\end{array}$ \\
\hline Gender & female & $53(41)$ \\
Age groups & $18-30$ & $77(59)$ \\
& $31-43$ & $41(32)$ \\
& $44-56$ & $35(27)$ \\
Residence & $57-69$ & $38(29)$ \\
Education & $70-80$ & $12(9)$ \\
& City & $4(3)$ \\
& County & $103(79)$ \\
Financial status & Elementary education & $27(21)$ \\
& High school & $3(2)$ \\
& College & $67(52)$ \\
& University and above & $21(16)$ \\
& Good & $79(30)$ \\
Any missing teeth? & Yes & $78(60)$ \\
& No & $42(32)$ \\
& & $3(2)$ \\
& Excellent & $94(72)$ \\
& & $36(28)$ \\
& & $130(100)$ \\
\hline \multirow{5}{*}{ Total } & &
\end{tabular}

possibility of implant placement and $90 \%$ would like to know more about dental implants (Table 3).

There is no significant difference in respondents' knowledge of dental implants in relation to gender (Table 4).

Subjects would be significantly more likely to know more about dental implants as opposed to subjects $\left(\mathrm{X}^{2}\right.$ test, $p=0.02)$. In other attitudes, there is no significant difference in relation to gender (Table 5).

Subjects in the age group of 70 to 80 years significantly considered that the dental implant was ceramic in its composition ( $\mathrm{X}^{2}$ test, $\left.\mathrm{p}=0.04\right)$ and significantly did not know how long the dental implant lasted ( $\mathrm{x}^{2}$ test, $\mathrm{p}=$ 0.006 ) in contrast to younger subjects. age groups (Table $6)$.

Subjects of all age groups up to 70 years are significantly more familiar with the possibility of dental implants ( $\mathrm{X}^{2}$ test, $\mathrm{p}=0.02$ ) than respondents of the age group 70 to 80 years who do not significantly know the possibility of dental implants as a source of information $\left(\mathrm{X}^{2}\right.$ test, $\left.\mathrm{p}=0.03\right)($ Table 7$)$.

There is no significant difference in the respondents' knowledge of dental implants with regard to the place of residence (Table 8).

There is no significant difference in the attitudes of the respondents about dental implants with regard to the possibility of information (Table 9).
TABLE 2

PATIENTS' KNOWLEDGE ABOUT DENTAL IMPLANTS

\begin{tabular}{|c|c|c|}
\hline Question & & $\begin{array}{l}\text { Number of } \\
\text { subjects (\%) }\end{array}$ \\
\hline \multirow{4}{*}{$\begin{array}{l}\text { Do you think it is } \\
\text { important to } \\
\text { replace the } \\
\text { extracted teeth? }\end{array}$} & It doesn't matter at all & $1(1)$ \\
\hline & $\begin{array}{l}\text { Neither important nor } \\
\text { unimportant }\end{array}$ & $5(4)$ \\
\hline & Somewhat important & $44(34)$ \\
\hline & Very important & $80(61)$ \\
\hline \multirow{4}{*}{$\begin{array}{l}\text { Where do you think } \\
\text { dental implants are } \\
\text { placed? }\end{array}$} & Into the bone & $96(74)$ \\
\hline & Into the gums & $23(17)$ \\
\hline & Into the adjacent teeth & $5(4)$ \\
\hline & Onto the adjacent teeth & $6(5)$ \\
\hline \multirow{5}{*}{$\begin{array}{l}\text { In your opinion, } \\
\text { what is the } \\
\text { composition of a } \\
\text { dental implant? }\end{array}$} & Porcelain & $19(15)$ \\
\hline & Stainless steel & $11(8)$ \\
\hline & Titan & $52(40)$ \\
\hline & Ceramics & $19(15)$ \\
\hline & I do not know & $29(22)$ \\
\hline \multirow{4}{*}{$\begin{array}{l}\text { How long do you } \\
\text { think is a lifespan } \\
\text { of a dental implant? }\end{array}$} & $5-10$ years & $14(11)$ \\
\hline & More than 10 years & $39(30)$ \\
\hline & Life long & $51(39)$ \\
\hline & I do not know & $26(20)$ \\
\hline \multirow{4}{*}{$\begin{array}{l}\text { Do you think that } \\
\text { dental implants } \\
\text { need special care } \\
\text { and hygiene? }\end{array}$} & No special care is required & $14(11)$ \\
\hline & It requires very little care & $4(3)$ \\
\hline & Same as natural teeth & $96(74)$ \\
\hline & $\begin{array}{l}\text { Much more than natural } \\
\text { teeth }\end{array}$ & $16(12)$ \\
\hline \multirow{5}{*}{$\begin{array}{l}\text { Who do you think } \\
\text { is qualified for } \\
\text { dental implant } \\
\text { placement? }\end{array}$} & Oral surgeons & $97(75)$ \\
\hline & Prosthetists & $19(15)$ \\
\hline & Periodontists & $1(1)$ \\
\hline & Cosmetic dentists & $2(2)$ \\
\hline & $\begin{array}{l}\text { General dental } \\
\text { practitioners }\end{array}$ & $11(8)$ \\
\hline Total & & $130(100)$ \\
\hline
\end{tabular}

In subjects with a university degree, the replacement of extracted teeth is significantly more important than in those with a lower level of education ( $x^{2}$ test, $p=0.03$ ). While subjects with completed primary school do not significantly know how long a dental implant lasts, unlike subjects with completed secondary, higher, and tertiary education ( $\mathrm{X}^{2}$ test, $\mathrm{p}=0.03$ ) (Table 10).

Subjects with completed primary school no longer know the available options for treatment with dental implants ( $x^{2}$ test, $p<0.001$ ) and as a source of information do not know the possibility of implantation of dental implants, unlike respondents with completed secondary, higher or higher education who are more often their source of information is their dentist ( $\mathrm{X}^{2}$ test, $\left.\mathrm{p}=0.004\right)$ and the cost of the installation procedure is a significantly important factor in deciding on the placement of a dental implant $\left(\mathrm{x}^{2}\right.$ test, $\left.\mathrm{p}=0.01\right)$ (Table 11$)$. 


\section{TABLE 3}

PATIENTS' ATTITUDE TOWARDS DENTAL IMPLANTS

\begin{tabular}{|c|c|c|}
\hline & & $\begin{array}{r}\text { Number of } \\
\text { subjects (\%) }\end{array}$ \\
\hline \multirow{4}{*}{$\begin{array}{l}\text { To what extent } \\
\text { are you familiar } \\
\text { with the different } \\
\text { treatment } \\
\text { options? }\end{array}$} & I do not know & $7(5)$ \\
\hline & Very little & $26(20)$ \\
\hline & To some extent & $73(56)$ \\
\hline & To a large degree & $24(18)$ \\
\hline \multirow{2}{*}{$\begin{array}{l}\text { Are you familiar } \\
\text { with the possibil- } \\
\text { ity of placing } \\
\text { dental implants? }\end{array}$} & I am familiar & $106(82)$ \\
\hline & I am not familiar & $24(18)$ \\
\hline \multirow{5}{*}{$\begin{array}{l}\text { What is your } \\
\text { main source of } \\
\text { information } \\
\text { regarding } \\
\text { implants? }\end{array}$} & Dentist & $62(48)$ \\
\hline & Friends and relatives & $24(18)$ \\
\hline & Media & $10(8)$ \\
\hline & Internet sources & $25(19)$ \\
\hline & $\begin{array}{l}\text { I am not familiar with the } \\
\text { possibility of dental implant } \\
\text { placement }\end{array}$ & $9(7)$ \\
\hline \multirow{4}{*}{$\begin{array}{l}\text { What is the most } \\
\text { important factor } \\
\text { in deciding on a } \\
\text { dental implant? }\end{array}$} & Cost of the procedure & $77(59)$ \\
\hline & Fear of surgery & $20(15)$ \\
\hline & $\begin{array}{l}\text { I do not like having a foreign } \\
\text { body inside me. }\end{array}$ & $9(7)$ \\
\hline & None & $24(19)$ \\
\hline \multirow{2}{*}{$\begin{array}{l}\text { Would you like to } \\
\text { know more about } \\
\text { dental implants? }\end{array}$} & Yes & $117(90)$ \\
\hline & No & $13(10)$ \\
\hline Total & & $130(100)$ \\
\hline
\end{tabular}

\section{Discussion}

A total of 130 patients who agreed to complete the questionnaire at the time of the study were included in the study. In terms of gender, $41 \%$ of male respondents and $59 \%$ of female respondents participated in the study. A similar study was conducted in 2013 at a dental clinic in Khartoum, Sudan on a sample of 384 patients, and of the total number of patients, $47.1 \%$ were male and $52.9 \%$ were female ${ }^{11}$.

The majority of respondents, $72 \%$, state that they lack at least one tooth, while only $28 \%$ of respondents state that they have all teeth. A similar study was conducted in 2016 on 100 patients in India and found that 54\% of them were missing at least one tooth, while $46 \%$ had all teeth $^{12}$. It can be seen that most patients in both studies are missing at least one tooth, but in the current study, the percentage of patients without at least one tooth is significantly higher.Taking into account the total number of subjects, the largest number of subjects showed a good level of knowledge related to dental implants.

The majority of respondents, $61 \%$ of them, believe that the replacement of extracted teeth is very important. Similar results were obtained in a study of the Austrian population as well as the population of subjects in the Hong Kong, SiChuan, and JiangSua areas where sub- jects showed an objective level of general knowledge about dental implants ${ }^{13-15}$. However, a study conducted in the Malaysian population shows only $17 \%$ of well-informed respondents about the possibility of replacing missing teeth with implants ${ }^{16}$.

In our study, respondents had to answer a question about the location of a dental implant, and most patients, 96 of them (74\%), believe that a dental implant is placed in a bone. A similar result on a total sample of 544 subjects, 418 of them (76.8\%) on the location of dental implant placement was shown by a study in Turkey ${ }^{17}$. In a study conducted in Sudan, $25.5 \%$ of patients believe that a dental implant is implanted in the bone ${ }^{11}$. Likewise, in a study conducted by Em Kalala-Kazadi et al. ${ }^{18}$, when asked about anchor implants, $86 \%$ of respondents did not know where a dental implant was placed. If we compare these data with our research, we can conclude that the patients from our research showed a higher level of knowledge.

When asked about the composition of a dental implant, the largest number of respondents, 52 of them (40\%), believe that the implant is made of titanium. A similar result was shown by a study in Turkey where $42.5 \%$ of participants did not know what implants were made of ${ }^{17}$.

When asked about the duration of a dental implant, the largest number of respondents, 51 (39\%), believe that a dental implant lasts a lifetime, while 39 (30\%) believe that a dental implant lasts more than 10 years, which is also true. Respondents to a study conducted in Sudan had to answer the same question where $19.3 \%$ of them believe that a dental implant lasts a lifetime, while only $7.3 \%$ think it lasts more than 10 years ${ }^{11}$. Also, a study conducted in Congo showed $92 \%$ of respondents did not know how long an implant lasts, and only $6 \%$ believe that a dental implant lasts a lifetime ${ }^{18}$. A majority of respondents (52.5\%) said that implants would last for about 10 years, and only $21.7 \%$ of participants said they were for life, according to a study conducted at the University of Michigan ${ }^{19}$. Research conducted by Mayya et al. is consistent with this study and shows that $76.7 \%$ of respondents believe that implants will last for 10 years, and only $9.3 \%$ for life ${ }^{20}$.

The majority of respondents in the current study, 96 of them (74\%), believe that a dental implant needs the same hygiene as natural teeth. Taking into account the total number of respondents, a study conducted in Sudan gave worse results than ours and showed that the largest number of respondents, $49.7 \%$, believe that dental implants need the same hygiene as natural teeth ${ }^{11}$. A study conducted in Italy showed that $60 \%$ of respondents said that implants need more care than natural teeth ${ }^{20}$. These data are consistent with another study where subjects felt in $79 \%$ that implants needed more care than natural teeth $^{20}$. In contrast, research conducted by Tepper et al. ${ }^{22}$, and Pommer et al. ${ }^{23}$ showed that only $45 \%$ and $39 \%$ of respondents, respectively, believe that dental implants need more care than natural teeth. 
TABLE 4

PATIENT'S KNOWLEDGE OF DENTAL IMPLANTS BY GENDER

\begin{tabular}{|c|c|c|c|c|}
\hline \multirow{2}{*}{ Knowledge } & \multicolumn{3}{|c|}{ Number (\%) of respondents } & \multirow{2}{*}{$\mathrm{P}^{*}$} \\
\hline & Male & Female & Total & \\
\hline \multicolumn{5}{|c|}{ Do you think the replacement of extracted teeth is important? } \\
\hline Not important at all & $1(2)$ & $0(0)$ & $1(1)$ & \multirow[t]{4}{*}{0.53} \\
\hline Neither important nor unimportant & $2(4)$ & $3(4)$ & $5(4)$ & \\
\hline Somewhat important & $20(38)$ & $24(31)$ & $44(34)$ & \\
\hline Very important & $30(56)$ & $50(65)$ & $80(61)$ & \\
\hline \multicolumn{5}{|c|}{ Where do you think dental implants are placed? } \\
\hline In the bone & $39(74)$ & $57(74)$ & $96(74)$ & \multirow[t]{4}{*}{0.33} \\
\hline In the mucosa & $7(13)$ & $16(20)$ & $23(17)$ & \\
\hline Inside adjacent teeth & $3(6)$ & $2(3)$ & $5(4)$ & \\
\hline On adjacent teeth & $4(7)$ & $2(3)$ & $6(5)$ & \\
\hline \multicolumn{5}{|c|}{ In your opinion, what is the composition of a dental implant? } \\
\hline Porcelain & $7(13)$ & $12(16)$ & $19(15)$ & \multirow[t]{5}{*}{0.99} \\
\hline Stainless Steel & $5(9)$ & $6(8)$ & $11(8)$ & \\
\hline Titan & $21(40)$ & $31(40)$ & $52(40)$ & \\
\hline Ceramics & $8(15)$ & $11(14)$ & $19(15)$ & \\
\hline I don't know & $12(23)$ & $17(22)$ & $29(22)$ & \\
\hline \multicolumn{5}{|c|}{ How long do you think a dental implant lasts? } \\
\hline $5-10$ years & $6(12)$ & $8(10)$ & $14(11)$ & \multirow[t]{4}{*}{0.47} \\
\hline More than 10 years & $14(26)$ & $25(33)$ & $39(30)$ & \\
\hline Lifetime & $19(36)$ & $32(42)$ & $51(39)$ & \\
\hline I don't know & $14(26)$ & $12(15)$ & $26(20)$ & \\
\hline \multicolumn{5}{|c|}{$\begin{array}{l}\text { Do you think that dental implants need special care and hygiene compared to natural } \\
\text { teeth? }\end{array}$} \\
\hline No special care required & $7(13)$ & $7(9)$ & $14(11)$ & \multirow[t]{4}{*}{0.25} \\
\hline Very little care is needed & $3(6)$ & $1(1)$ & $4(3)$ & \\
\hline Same as natural teeth & $39(74)$ & $57(75)$ & $96(74)$ & \\
\hline Much more than natural teeth & $4(7)$ & $12(15)$ & $16(12)$ & \\
\hline \multicolumn{5}{|c|}{ Who do you think is qualified to place dental implants? } \\
\hline Oral Surgeons & $41(78)$ & $56(73)$ & $97(75)$ & \multirow[t]{6}{*}{0.45} \\
\hline Prosthetics & $6(11)$ & $13(17)$ & $19(15)$ & \\
\hline Periodontists & $1(2)$ & $0(0)$ & $1(1)$ & \\
\hline Cosmetic dentists & $0(0)$ & $2(2)$ & $2(2)$ & \\
\hline General dentists & $5(9)$ & $6(8)$ & $11(8)$ & \\
\hline Total & $53(100)$ & $77(100)$ & $130(100)$ & \\
\hline
\end{tabular}

When asked who is qualified to place dental implants, the majority of respondents in our study, 97 of them (75\%), believe that oral surgeons are trained to do so. A study conducted in Austria shows that most respondents believe that only specialists should perform implant procedures ${ }^{14}$.

A statistically significant difference in our study was observed in the knowledge of patients in relation to age and level of education. It was found that respondents in the age group of 70 to 80 years significantly more consid- er that the dental implant is ceramic in its composition and significantly do not know how long the dental implant lasts compared to respondents in younger age groups. In addition, it was found that for respondents with a university degree, significantly more extraction of extracted teeth is very important in contrast to respondents with lower education. Unlike respondents with completed secondary, higher, and tertiary education, respondents with completed primary school do not significantly know how long a dental implant lasts. 
TABLE 5

ATTITUDES OF RESPONDENTS ABOUT DENTAL IMPLANTS BY GENDER

\begin{tabular}{|c|c|c|c|c|}
\hline \multirow[t]{2}{*}{ Attitudes } & \multicolumn{3}{|c|}{ Number (\%) of respondents } & \multirow[t]{2}{*}{$\mathrm{P}^{*}$} \\
\hline & Male & Female & Total & \\
\hline \multicolumn{5}{|c|}{ To what extent do you know the different treatment options available? } \\
\hline I don't know & $4(7)$ & $3(4)$ & $7(5)$ & \multirow[t]{4}{*}{0.80} \\
\hline Very little & $11(21)$ & $15(19)$ & $26(20)$ & \\
\hline Somewhat & $28(53)$ & $45(59)$ & $73(56)$ & \\
\hline Large & $10(19)$ & $14(18)$ & $24(18)$ & \\
\hline \multicolumn{5}{|c|}{ Do you know the possibility of inserting dental implants? } \\
\hline I know & $43(81)$ & $63(82)$ & $106(82)$ & \multirow[t]{2}{*}{0.92} \\
\hline I don't know & $10(19)$ & $14(18)$ & $24(18)$ & \\
\hline \multicolumn{5}{|l|}{ What is the source of your information? } \\
\hline Dentist & $21(40)$ & $41(53)$ & $62(48)$ & \multirow[t]{5}{*}{0.09} \\
\hline Friends and relatives & $8(15)$ & $16(21)$ & $24(18)$ & \\
\hline Media & $7(13)$ & $3(4)$ & $10(8)$ & \\
\hline Internet Resources & $11(21)$ & $14(18)$ & $25(19)$ & \\
\hline $\begin{array}{l}\text { I do not know the possibility of inserting } \\
\text { dental implants }\end{array}$ & $6(11)$ & $3(4)$ & $9(7)$ & \\
\hline \multicolumn{5}{|c|}{ What is the most important factor in deciding on a dental implant? } \\
\hline Costs of proceedings & $33(62)$ & $44(57)$ & $77(59)$ & \multirow[t]{4}{*}{0.13} \\
\hline Fear of surgery & $4(7)$ & $16(21)$ & $20(15)$ & \\
\hline $\begin{array}{l}\text { I don't like a foreign body located in my } \\
\text { body }\end{array}$ & $3(6)$ & $6(7)$ & $9(7)$ & \\
\hline None & $13(25)$ & $11(14)$ & $24(19)$ & \\
\hline \multicolumn{5}{|c|}{ Would you like to know more about dental implants? } \\
\hline Yes & $44(83)$ & $73(95)$ & $117(90)$ & \multirow[t]{3}{*}{0.02} \\
\hline No & $9(17)$ & $4(5)$ & $13(10)$ & \\
\hline Total & $53(100)$ & $77(100)$ & $130(100)$ & \\
\hline
\end{tabular}

Awareness of dental implants was statistically significant in relation to the age of the subjects and their level of education in a study conducted in Croatia where it was shown that younger people with a higher level of education have better information about implants ${ }^{24}$. Also, statistically significant differences were found between the age and socio-economic status of the population of northern India in a study conducted by Kour et al..$^{25}$. These data are consistent with what was reported by Yao et al. that younger subjects ( $<45$ years) and those with a higher level of education (bachelor and postgraduate) tended to show a more realistic perception and lower expectations of the outcome of implant therapy ${ }^{15}$. A survey of the Saudi population also found that more than $50 \%$ of respondents referred for implants had education level higher than a bachelor's degree. This percentage was significantly higher than those referring to who could only read and write or who were bachelors ${ }^{26}$.

The largest number of respondents, 73 of them (56\%), only partially know the possibilities of replacing a lost tooth, while the majority of respondents, 106 of them (82\%), know the possibilities of installing a dental im- plant. A study conducted in Sudan showed that $68.5 \%$ of their respondents were aware of the possibility of installing dental implants ${ }^{11}$. In contrast, in a study by Tandra Das et al., $70 \%$ of respondents did not know the possibility of implant placement ${ }^{27}$.

When asked about the source of information related to dental implants, the majority of respondents, 62 of them (48\%), stated that the dentist is the main source of their knowledge about dental implants. A survey conducted in 1998 in the Netherlands showed that $52 \%$ of respondents first heard information about dental implants from friends and relatives while $36 \%$ received the first information from a family dentist ${ }^{13}$. As the main source of information related to dental implants research, Pradha et al. ${ }^{28}$, as well as Alshammari et al. ${ }^{29}$ also state that the dentist is the main source of the knowledge of dental implants. The patient's interest in acquiring additional information related to dental implants leads to an attempt to seek additional information from other sources. Research done in England has shown the possibility of displaying false information about implants in various media ${ }^{30}$. 
TABLE 6

PATIENTS' KNOWLEDGE OF DENTAL IMPLANTS IN RELATION TO AGE

\begin{tabular}{|c|c|c|c|c|c|c|}
\hline \multirow{2}{*}{ Knowledge } & \multicolumn{5}{|c|}{ Number (\%) of respondents } & \multirow{2}{*}{$\mathrm{P}^{*}$} \\
\hline & $18-30$ & $31-43$ & $44-56$ & $57-69$ & $70-80$ & \\
\hline \multicolumn{7}{|c|}{ Do you think the replacement of extracted teeth is important? } \\
\hline It doesn't matter at all & $1(2)$ & $0(0)$ & $0(0)$ & $0(0)$ & $0(0)$ & \multirow[t]{4}{*}{0.09} \\
\hline Neither important nor unimportant & $3(7)$ & $0(0)$ & $1(3)$ & $1(8)$ & $0(0)$ & \\
\hline Somewhat important & $15(37)$ & $18(51)$ & $9(23)$ & $0(0)$ & $2(50)$ & \\
\hline Very important & $22(54)$ & $17(49)$ & $28(74)$ & $11(92)$ & $2(50)$ & \\
\hline \multicolumn{7}{|c|}{ Where do you think dental implants are placed? } \\
\hline In the bone & $29(71)$ & $27(77)$ & $31(81)$ & $7(59)$ & $2(50)$ & \multirow[t]{4}{*}{0.64} \\
\hline In the mucosa & $6(15)$ & $6(17)$ & $5(13)$ & $4(33)$ & $2(50)$ & \\
\hline Inside adjacent teeth & $3(7)$ & $1(3)$ & $1(3)$ & $0(0)$ & $0(0)$ & \\
\hline On adjacent teeth & $3(7)$ & $1(3)$ & $1(3)$ & $1(8)$ & $0(0)$ & \\
\hline \multicolumn{7}{|c|}{ In your opinion, what is the composition of a dental implant? } \\
\hline Porcelain & $9(22)$ & $2(6)$ & $6(16)$ & $2(17)$ & $0(0)$ & \multirow[t]{5}{*}{0.04} \\
\hline Stainless steel & $1(2)$ & $4(11)$ & $5(13)$ & $1(8)$ & $0(0)$ & \\
\hline Titan & $9(22)$ & $16(46)$ & $19(50)$ & $7(59)$ & $1(25)$ & \\
\hline Ceramics & $11(27)$ & $3(8)$ & $2(5)$ & $1(8)$ & $2(50)$ & \\
\hline I do not know & $11(27)$ & $10(29)$ & $6(16)$ & $1(8)$ & $1(25)$ & \\
\hline \multicolumn{7}{|c|}{ How long do you think a dental implant lasts? } \\
\hline $5-10$ years & $8(20)$ & $2(6)$ & $4(10)$ & $0(0)$ & $0(0)$ & \multirow[t]{4}{*}{0.006} \\
\hline More than 10 years & $13(32)$ & $13(37)$ & $8(21)$ & $5(42)$ & $0(0)$ & \\
\hline Lifetime & $14(34)$ & $14(40)$ & $20(53)$ & $3(25)$ & $0(0)$ & \\
\hline I do not know & $6(14)$ & $6(17)$ & $6(16)$ & $4(33)$ & $4(100)$ & \\
\hline \multicolumn{7}{|c|}{ Do you think that dental implants need special care and hygiene compared to natural teeth? } \\
\hline No special care is required & $3(7)$ & $7(20)$ & $4(11)$ & $0(0)$ & $0(0)$ & \multirow[t]{4}{*}{0.08} \\
\hline It requires very little care & $2(5)$ & $2(6)$ & $0(0)$ & $0(0)$ & $0(0)$ & \\
\hline Same as natural teeth & $28(68)$ & $23(66)$ & $33(87)$ & $8(67)$ & $4(100)$ & \\
\hline Much more than natural teeth & $8(20)$ & $3(8)$ & $1(2)$ & $4(33)$ & $0(0)$ & \\
\hline \multicolumn{7}{|c|}{ Who do you think is qualified to place dental implants? } \\
\hline Oral surgeons & $32(79)$ & $24(67)$ & $28(73)$ & $11(92)$ & $2(50)$ & \multirow[t]{6}{*}{0.63} \\
\hline Prosthetists & $5(12)$ & $5(14)$ & $6(16)$ & $1(8)$ & $2(50)$ & \\
\hline Periodontists & $1(2)$ & $0(0)$ & $0(0)$ & $0(0)$ & $0(0)$ & \\
\hline Cosmetic dentists & $1(2)$ & $0(0)$ & $1(3)$ & $0(0)$ & $0(0)$ & \\
\hline General practitioners & $2(5)$ & $6(17)$ & $3(8)$ & $0(0)$ & $0(0)$ & \\
\hline Total & $41(100)$ & $35(100)$ & $38(100)$ & $12(100)$ & $4(100)$ & \\
\hline
\end{tabular}

TABLE 7

ATTITUDES OF RESPONDENTS ABOUT DENTAL IMPLANTS BY AGE

\begin{tabular}{lccccc}
\hline \multirow{2}{*}{ Attitude } & \multicolumn{5}{c}{ Number (\%) of respondents } \\
\cline { 2 - 5 } & $18-30$ & $31-43$ & $44-56$ & $57-69$ & $70-80$ \\
\hline To what extent do you know the different treatment & options available? \\
I do not know & $2(5)$ & $1(3)$ & $2(5)$ & $2(17)$ & $0(0)$ \\
Very little & $11(27)$ & $7(20)$ & $6(16)$ & $1(8)$ & $1(25)$ \\
To some extent & $21(52)$ & $22(63)$ & $20(53)$ & $8(67)$ & $2(50)$ \\
Largely & $7(17)$ & $5(14)$ & $10(26)$ & $1(8)$ & $1(25)$ \\
\hline
\end{tabular}


TABLE 7

CONTINUED..

\begin{tabular}{|c|c|c|c|c|c|c|}
\hline \multirow{2}{*}{ Attitude } & \multicolumn{5}{|c|}{ Number (\%) of respondents } & \multirow{2}{*}{$\mathrm{P}^{*}$} \\
\hline & $18-30$ & $31-43$ & $44-56$ & $57-69$ & $70-80$ & \\
\hline \multicolumn{7}{|c|}{ Do you know the possibility of inserting dental implants? } \\
\hline I know & $34(83)$ & $31(89)$ & $32(84)$ & $8(67)$ & $1(25)$ & 0.02 \\
\hline I do not know & $7(17)$ & $4(11)$ & $6(16)$ & $4(33)$ & $3(75)$ & \\
\hline \multicolumn{7}{|c|}{ What is the source of your information? } \\
\hline Dentist & $18(44)$ & $19(54)$ & $19(50)$ & $5(43)$ & $1(25)$ & 0.03 \\
\hline Friends and relatives & $11(27)$ & $3(9)$ & $8(21)$ & $1(8)$ & $1(25)$ & \\
\hline Media & $2(5)$ & $4(11)$ & $2(5)$ & $2(17)$ & $0(0)$ & \\
\hline Internet sources & $8(19)$ & $8(23)$ & $8(21)$ & $1(8)$ & $25(19)$ & \\
\hline $\begin{array}{l}\text { I do not know the possibility of } \\
\text { inserting dental implants }\end{array}$ & $2(5)$ & $1(3)$ & $1(3)$ & $3(25)$ & $2(50)$ & \\
\hline \multicolumn{7}{|c|}{ What is the most important factor in deciding on a dental implant? } \\
\hline Costs of the proceedings & $22(54)$ & $23(66)$ & $23(61)$ & $5(42)$ & $4(100)$ & 0.61 \\
\hline Fear of surgery & $7(17)$ & $5(14)$ & $7(18)$ & $1(8)$ & $0(0)$ & \\
\hline $\begin{array}{l}\text { I don't like a foreign body } \\
\text { located in my body }\end{array}$ & $4(10)$ & $1(3)$ & $3(8)$ & $1(8)$ & $0(0)$ & \\
\hline None & $8(19)$ & $6(17)$ & $5(13)$ & $5(42)$ & $0(0)$ & \\
\hline \multicolumn{7}{|c|}{ Would you like to know more about dental implants? } \\
\hline Yes & $38(93)$ & $29(83)$ & $35(92)$ & $12(100)$ & $3(75)$ & 0.31 \\
\hline No & $3(7)$ & $6(17)$ & $3(8)$ & $0(0)$ & $1(25)$ & \\
\hline Total & $41(100)$ & $35(100)$ & $38(100)$ & $12(100)$ & $4(100)$ & \\
\hline
\end{tabular}

${ }^{*} \mathrm{X}^{2}$ test

TABLE 8

PATIENTS' KNOWLEDGE OF DENTAL IMPLANTS BY PLACE OF RESIDENCE

\begin{tabular}{lcccc}
\hline \multirow{2}{*}{ Knowledge } & \multicolumn{3}{c}{ Number (\%) of respondents } & \multirow{2}{*}{ P $^{*}$} \\
\cline { 2 - 3 } & City & Village & Total & \\
\hline Do you think the replacement of extracted teeth is important? & & & \\
It doesn't matter at all & $1(1)$ & $0(0)$ & $1(1)$ & 0.63 \\
Neither important nor unimportant & $5(5)$ & $0(0)$ & $5(4)$ & \\
Somewhat important & $35(34)$ & $9(13)$ & $44(34)$ & \\
Very important & $62(60)$ & $18(67)$ & $80(61)$ & \\
Where do you think dental implants are placed? & & & \\
In the bone & $76(74)$ & $20(74)$ & $96(74)$ & 0.44 \\
In the mucosa & $18(17)$ & $5(19)$ & $23(17)$ & \\
Inside adjacent teeth & $3(3)$ & $2(7)$ & $5(4)$ & \\
On adjacent teeth & $6(6)$ & $0(0)$ & $6(5)$ & \\
In your opinion, what is the composition of a dental implant? & & \\
Porcelain & $12(12)$ & $7(26)$ & $19(15)$ & 0.19 \\
Stainless steel & $11(11)$ & $0(0)$ & $11(8)$ & \\
Titan & $41(40)$ & $11(41)$ & $52(40)$ & \\
Ceramics & $16(15)$ & $3(11)$ & $19(15)$ & \\
I do not know & $23(22)$ & $6(21)$ & $29(22)$ & \\
\hline
\end{tabular}


TABLE 8

CONTINUED...

\begin{tabular}{|c|c|c|c|c|}
\hline \multirow{2}{*}{ Knowledge } & \multicolumn{3}{|c|}{ Number (\%) of respondents } & \multirow{2}{*}{$\mathrm{P}^{*}$} \\
\hline & City & Village & Total & \\
\hline \multicolumn{5}{|c|}{ How long do you think a dental implant lasts? } \\
\hline $5-10$ years & $12(12)$ & $2(7)$ & $14(11)$ & 0.71 \\
\hline More than 10 years & $29(28)$ & $10(37)$ & $39(30)$ & \\
\hline Lifetime & $40(39)$ & $11(41)$ & $51(39)$ & \\
\hline I do not know & $22(21)$ & $4(15)$ & $26(20)$ & \\
\hline \multicolumn{5}{|c|}{$\begin{array}{l}\text { Do you think that dental implants need special care and hygiene compared to } \\
\text { natural teeth? }\end{array}$} \\
\hline No special care is required & $11(11)$ & $3(11)$ & $14(11)$ & 0.57 \\
\hline It requires very little care & $4(4)$ & $0(0)$ & $4(3)$ & \\
\hline Same as natural teeth & $74(72)$ & $22(82)$ & $96(74)$ & \\
\hline Much more than natural teeth & $14(13)$ & $2(7)$ & $16(12)$ & \\
\hline \multicolumn{5}{|c|}{ Who do you think is qualified to place dental implants? } \\
\hline Oral surgeons & $78(76)$ & $19(70)$ & $97(75)$ & 0.32 \\
\hline Prosthetists & $15(14)$ & $4(15)$ & $19(15)$ & \\
\hline Periodontists & $0(0)$ & $1(4)$ & $1(1)$ & \\
\hline Cosmetic dentists & $2(2)$ & $0(0)$ & $2(2)$ & \\
\hline General practitioners & $8(8)$ & $3(11)$ & $11(8)$ & \\
\hline Total & $103(100)$ & $27(100)$ & $130(100)$ & \\
\hline
\end{tabular}

TABLE 9

ATTITUDES OF RESPONDENTS ABOUT DENTAL IMPLANTS BY PLACE OF RESIDENCE

\begin{tabular}{|c|c|c|c|c|}
\hline \multirow{2}{*}{ Attitudes } & \multicolumn{3}{|c|}{ Number (\%) of respondents } & \multirow{2}{*}{$\mathrm{P}^{*}$} \\
\hline & City & Village & Total & \\
\hline \multicolumn{5}{|c|}{ To what extent do you know the different treatment options available? } \\
\hline I do not know & $6(6)$ & $1(4)$ & $7(5)$ & \multirow[t]{4}{*}{0.36} \\
\hline Very little & $20(19)$ & $6(22)$ & $26(20)$ & \\
\hline To some extent & $55(54)$ & $18(67)$ & $73(56)$ & \\
\hline Largely & $22(21)$ & $2(7)$ & $24(18)$ & \\
\hline \multicolumn{5}{|c|}{ Do you know the possibility of installing dental implants? } \\
\hline I know & $85(83)$ & $21(78)$ & $106(82)$ & \multirow[t]{2}{*}{0.57} \\
\hline I do not know & $18(17)$ & $6(22)$ & $24(18)$ & \\
\hline \multicolumn{5}{|l|}{ What is the source of your information? } \\
\hline Dentist & $49(48)$ & $13(48)$ & $62(48)$ & \multirow[t]{5}{*}{0.94} \\
\hline Friends and relatives & $20(19)$ & $4(15)$ & $24(18)$ & \\
\hline Media & $7(7)$ & $3(11)$ & $10(8)$ & \\
\hline Internet sources & $20(19)$ & $5(19)$ & $25(19)$ & \\
\hline $\begin{array}{l}\text { I do not know the possibility of inserting } \\
\text { dental implants }\end{array}$ & $7(7)$ & $2(7)$ & $9(7)$ & \\
\hline
\end{tabular}


TABLE 9

CONTINUED..

\begin{tabular}{|c|c|c|c|c|}
\hline \multirow{2}{*}{ Attitudes } & \multicolumn{3}{|c|}{ Number (\%) of respondents } & \multirow{2}{*}{$\mathrm{P}^{*}$} \\
\hline & City & Village & Total & \\
\hline \multicolumn{5}{|c|}{ What is the most important factor in deciding on a dental implant? } \\
\hline Costs of proceedings & $62(60)$ & $15(56)$ & $77(59)$ & \multirow[t]{4}{*}{0.71} \\
\hline Fear of surgery & $14(14)$ & $6(22)$ & $20(15)$ & \\
\hline $\begin{array}{l}\text { I don't like a foreign body located in my } \\
\text { body }\end{array}$ & $7(7)$ & $2(7)$ & $9(7)$ & \\
\hline None & $20(19)$ & $4(15)$ & $24(19)$ & \\
\hline \multicolumn{5}{|c|}{ Would you like to know more about dental implants? } \\
\hline Yes & $91(88)$ & $26(96)$ & $117(90)$ & \multirow[t]{3}{*}{0.22} \\
\hline No & $12(12)$ & $1(4)$ & $13(10)$ & \\
\hline Total & $103(100)$ & $27(100)$ & $130(100)$ & \\
\hline
\end{tabular}

TABLE 10

PATIENTS' KNOWLEDGE OF DENTAL IMPLANTS BY EDUCATION LEVEL

\begin{tabular}{|c|c|c|c|c|c|c|}
\hline \multirow[t]{2}{*}{ Knowledge } & \multicolumn{5}{|c|}{ Number (\%) of respondents } & \multirow[t]{2}{*}{$\mathrm{P}^{*}$} \\
\hline & Primary school & Secondary education & Higher education & Tertiary education & Total & \\
\hline \multicolumn{7}{|c|}{ Do you think the replacement of extracted teeth is important? } \\
\hline It doesn't matter at all & $0(0)$ & $0(0)$ & $1(5)$ & $0(0)$ & $1(1)$ & \multirow[t]{4}{*}{0.03} \\
\hline $\begin{array}{l}\text { Neither important nor } \\
\text { unimportant }\end{array}$ & $1(33)$ & $3(5)$ & $1(5)$ & $0(0)$ & $5(4)$ & \\
\hline Somewhat important & $1(33)$ & $23(34)$ & $10(48)$ & $10(26)$ & $44(34)$ & \\
\hline Very important & $1(33)$ & $41(61)$ & $9(42)$ & $29(74)$ & $80(61)$ & \\
\hline \multicolumn{7}{|c|}{ Where do you think dental implants are placed? } \\
\hline In the bone & $1(33)$ & $47(70)$ & $19(90)$ & $29(74)$ & $96(74)$ & \multirow[t]{4}{*}{0.16} \\
\hline In the mucosa & $1(33)$ & $13(19)$ & $1(5)$ & $8(21)$ & $23(17)$ & \\
\hline Inside adjacent teeth & $0(0)$ & $4(6)$ & $1(5)$ & $0(0)$ & $5(4)$ & \\
\hline On adjacent teeth & $1(33)$ & $3(5)$ & $0(0)$ & $2(5)$ & $6(5)$ & \\
\hline \multicolumn{7}{|c|}{ In your opinion, what is the composition of a dental implant? } \\
\hline Porcelain & $2(67)$ & $8(12)$ & $2(10)$ & $7(18)$ & $19(15)$ & \multirow[t]{5}{*}{0.63} \\
\hline Stainless steel & $0(0)$ & $5(7)$ & $2(10)$ & $4(10)$ & $11(8)$ & \\
\hline Titan & $0(0)$ & $30(45)$ & $8(38)$ & $14(36)$ & $52(40)$ & \\
\hline Ceramics & $0(0)$ & $10(15)$ & $4(19)$ & $5(13)$ & $19(15)$ & \\
\hline I do not know & $1(33)$ & $14(21)$ & $5(23)$ & $9(23)$ & $29(22)$ & \\
\hline \multicolumn{7}{|c|}{ How long do you think a dental implant lasts? } \\
\hline $5-10$ years & $0(0)$ & $5(7)$ & $3(14)$ & $6(15)$ & $14(11)$ & \multirow[t]{4}{*}{0.03} \\
\hline More than 10 years & $0(0)$ & $19(29)$ & $6(29)$ & $14(36)$ & $39(30)$ & \\
\hline Lifetime & $0(0)$ & $26(39)$ & $10(48)$ & $15(39)$ & $51(39)$ & \\
\hline I do not know & $3(100)$ & $17(25)$ & $2(9)$ & $4(10)$ & $26(20)$ & \\
\hline \multicolumn{7}{|c|}{ Do you think that dental implants need special care and hygiene compared to natural teeth? } \\
\hline No special care is required & $0(0)$ & $9(13)$ & $3(14)$ & $2(5)$ & $14(11)$ & \multirow[t]{4}{*}{0.83} \\
\hline It requires very little care & $0(0)$ & $1(2)$ & $1(5)$ & $2(5)$ & $4(3)$ & \\
\hline Same as natural teeth & $2(67)$ & $50(75)$ & $14(67)$ & $30(77)$ & $96(74)$ & \\
\hline Much more than natural teeth & $1(33)$ & $7(10)$ & $3(14)$ & $5(13)$ & $16(12)$ & \\
\hline
\end{tabular}


TABLE 10

CONTINUED...

\begin{tabular}{lccccc}
\hline Who do you think is qualified to place dental implants? & & & & \\
Oral surgeons & $2(67)$ & $51(76)$ & $16(76)$ & $28(73)$ & $97(75)$ \\
Prosthetists & $1(33)$ & $6(9)$ & $3(14)$ & $9(23)$ & $19(15)$ \\
Periodontists & $0(0)$ & $1(2)$ & 0 & 0 & $1(1)$ \\
Cosmetic dentists & $0(0)$ & $1(2)$ & 0 & $1(2)$ & $2(2)$ \\
General practitioners & $0(0)$ & $8(11)$ & $2(10)$ & $1(2)$ & $11(8)$ \\
Total & $3(100)$ & $67(100)$ & $21(100)$ & $39(100)$ & $130(100)$ \\
\hline
\end{tabular}

${ }^{*} \mathrm{X}^{2}$ test

TABLE 11 ATTITUDES OF RESPONDENTS ABOUT DENTAL IMPLANTS BY EDUCATION LEVEL

\begin{tabular}{|c|c|c|c|c|c|c|}
\hline \multirow[b]{2}{*}{ Attitudes } & \multicolumn{5}{|c|}{ Number (\%) of respondents } & \multirow[b]{2}{*}{$\mathrm{P}^{*}$} \\
\hline & Primary school & $\begin{array}{l}\text { Secondary } \\
\text { education }\end{array}$ & $\begin{array}{l}\text { Higher } \\
\text { education }\end{array}$ & $\begin{array}{l}\text { Tertiary } \\
\text { education }\end{array}$ & Total & \\
\hline \multicolumn{7}{|c|}{ To what extent do you know the different treatment options available? } \\
\hline I do not know & $2(67)$ & $2(3)$ & $3(14)$ & $0(0)$ & $7(5)$ & \multirow[t]{4}{*}{$<0.001$} \\
\hline Very little & $0(0)$ & $12(18)$ & $5(24)$ & $9(23)$ & $26(20)$ & \\
\hline To some extent & $1(33)$ & $44(66)$ & $5(24)$ & $23(59)$ & $73(56)$ & \\
\hline Largely & $0(0)$ & $9(13)$ & $8(38)$ & $7(18)$ & $24(18)$ & \\
\hline \multicolumn{7}{|c|}{ Do you know the possibility of inserting dental implants? } \\
\hline I know & $1(33)$ & $52(78)$ & $19(90)$ & $34(87)$ & $106(82)$ & \multirow[t]{2}{*}{0.06} \\
\hline I do not know & $2(67)$ & $15(22)$ & $2(10)$ & $5(13)$ & $24(18)$ & \\
\hline \multicolumn{7}{|c|}{ What is the source of your information? } \\
\hline Dentist & $0(0)$ & $32(48)$ & $11(52)$ & $19(49)$ & $62(48)$ & \multirow[t]{5}{*}{0.004} \\
\hline Friends and relatives & $0(0)$ & $11(16)$ & $6(29)$ & $7(18)$ & $24(18)$ & \\
\hline Media & $0(0)$ & $6(9)$ & $3(14)$ & $1(3)$ & $10(8)$ & \\
\hline Internet sources & $1(33)$ & $13(19)$ & $0(0)$ & $11(28)$ & $25(19)$ & \\
\hline $\begin{array}{l}\text { I do not know the possibility of } \\
\text { inserting dental implants }\end{array}$ & $2(67)$ & $5(7)$ & $1(5)$ & $1(3)$ & $9(7)$ & \\
\hline \multicolumn{7}{|c|}{ What is the most important factor in deciding on a dental implant? } \\
\hline Costs of the proceedings & $1(33)$ & $43(64)$ & $10(48)$ & $23(59)$ & $77(59)$ & \multirow[t]{4}{*}{0.01} \\
\hline Fear of surgery & $0(0)$ & $9(13)$ & $5(23)$ & $6(15)$ & $20(15)$ & \\
\hline $\begin{array}{l}\text { I don't like a foreign body located } \\
\text { in my body }\end{array}$ & $2(67)$ & $4(6)$ & $2(10)$ & $1(3)$ & $9(7)$ & \\
\hline None & $0(0)$ & $11(16)$ & $4(19)$ & $9(23)$ & $24(19)$ & \\
\hline \multicolumn{7}{|c|}{ Would you like to know more about dental implants? } \\
\hline Yes & $3(100)$ & $60(90)$ & $20(95)$ & $34(87)$ & $117(90)$ & \multirow[t]{3}{*}{0.72} \\
\hline No & $0(0)$ & $7(10)$ & $1(5)$ & $5(13)$ & $13(10)$ & \\
\hline Total & $3(100)$ & $67(100)$ & $21(100)$ & 39 (100) & $130(100)$ & \\
\hline
\end{tabular}

${ }^{*} \mathrm{X}^{2}$ test

The majority of respondents in our study, 77 of them (59\%), state that the cost of the procedure is their most important factor when deciding on the installation of a dental implant. A previously mentioned study in India found that $54 \%$ of respondents cite the high cost of implants and the implantation procedure as a crucial factor for the decision to install a dental implant ${ }^{12}$. The results of these studies are consistent with the data by Kohli et al., Siddique et al. and Mahajani et al., showing that high costs are a major limiting factor for implant treatment $^{16,31,32}$.

\section{Conclusions}

Most of the respondents are missing at least one tooth, and most of them think that the replacement of the extracted teeth is very important. Most subjects know 
that a dental implant is placed in the bone, but they do not know its duration. Most respondents know that dental implants need the same hygiene as natural teeth and that they are installed by oral surgeons. The dentist is the main source of information about dental implants for most respondents, and the cost of the procedure is the main barrier in the decision to install a dental implant, but despite this most of them want to know more about dental implants. There was a difference in patients' knowledge of dental implants in relation to age and level of education as well as a significant difference in patients' attitudes about dental implants in relation to gender, age, and level of education.

\section{R E F E R E N C E S}

1. AHAMMED AY, BODDU S, THAREJA A, KANDASWAMY R, KUMAR N, (Mahajan) SB, J Contemp Dent Pract, 14 (2013) 115. doi: 10.5005/jp-journals-10024-1282. - 2. AHMED A, RAKAN A, ABDULR. A, FARIS A, SALEH A, Adv Dent \& Oral Health, 6/5 (2017) 5556968. doi: 10.19080/adoh.2017.06.555698. - 3. CARR BA, Brown TD, Removable Partial Prosthodontics (Elsevier, Canada, 2016). - 4. KRALJEVIĆ K, KRALJEVIĆ-ŠIMUNKOVIĆ S, Djelomične proteze (In. Tri d.o.o., zagreb, 2012). - 5. ESFAHANI FO, MOOSAALI F, J Periodontol Implant Dent, 8 (2016) 43. doi: 10.15171/jpid.2016.008. - 6. KNEŽEVIĆ G, JEROLIMOV V, SRDJAK JORGIĆ K, KOBLER P, VARGA S, ŽIVKO BABIĆ J, Osnove dentalne implantologije (Zagreb, Školska knjiga, 2002). - 7 . LINDE J, LANG PN, KARRING T, Klinička parodontologija i dentalna implantologija, sv 2 (Nakladni zavod Globus, zagreb, 2010). - 8. DEEB G, WHEELER B, JONES M, CARRICO C, LASKIN D, GOLOB DJ, J Oral Maxillofac Surg, 75 (2017) 1387. doi:10.1016/j.joms.2017.03.024. - 9. LUBINA L, ROMIĆ M, ILLEŠ D, Sonda, 10 (2009) 47. - 10. IVANKOVIĆ D, BOŽIKOV J, KERN J, KOPJAR B, LUKOVIĆ G, Osnove statističke analize za medicinare (Medicinski fakultet Sveučilišta u Zagrebu 1988). - 11. AWOODA ME, ELTAYEB SA, HUSSEIN AS, DAYELNAIEM IS, ABDELHAMIED AM, MOHAMED AL, TAHA S, IOSR Journal of Dental and Medical Sciences, 13/11 (2014) 19. doi:10.9790/0853-131161923. - 12. KUMAR MPS, MARUTHAMUTHU M, J Pharm Sci Res, 8 (2016) 351. - 13. KAPTEIN M. L, HOOGSTRATEN J, DE PUTTER C, DE LANGE GL, BLIJDORP PA, Clin Oral Implants Res, 9 (1998) 321. - 14. POMMER B, ZECHNER W, WATZAK G, ULM C, WATZEK G, TEPPER G, Clin Oral Implants Res, 22 (2011) 223. doi:10.1111/j.1600-0501.2010.02035.x. - 15. YAO J, LI M, TANG H, WANG PL, ZHAO YX, MCGRATH C, MATTHEOS N, Clin Oral Implants Res, 28 (2017) 261. doi: 10.1111/clr.12793. - 16. KOHLI S, BHATIA S, KAUR A, RATHAKRISHNAN T, Indian J Dent, 6 (2015) 167. doi: 10.4103/0975-962x.168518. - 17. ÖZTÜRK H, ÖZGEDIK H, AVSEVER

H, KURT M, ŞENEL B, PIŞKIN B, ORHAN K, J Stoma, 72 (2019) 112. doi: 10.5114/jos.2019.87526. - 18. KALALA-KAZADI E, DISIDI-YAKINI P, NYIMI-BUSHABA F, EKOFO-INGAYA E, MANTSHUMBAMILOLO A, Open Journal Of Stomatology, 8 (2018) 353. doi:10.4236/ ojst.2018.812033. - 19. INSUA A, MONJE A, WANG HL, INGLEHART M, J Periodontol, 88 (2017) 1153. doi:10.1902/jop.2017.160796. — 20. MAYYA A D'SOUZA J, GEORGE AM, SHENOY K, JODALLI P, MAYYA SS, Indian J Dent Res, 29 (2018) 263. doi:10.4103/ijdr.ijdr_92_17. — 21. BRUNELLO G, GERVASI M, RICCI S, TOMASI C, BRESSAN E, Clin Oral Implants Res, 31(2020) 917. doi: 10.1111/clr.13634. — 22. TEPPER G, HAAS R, MAILATH G, TELLER C, ZECHNER W, WATZAK G, WATZEK G, Clin Oral Implants Res, 14 (2003) 621. doi: 10.1034/j.1600-0501.2003.00916.x. - 23. POMMER B, ZECHNER W, WATZAK G, ULM C, WATZEK G, TEPPER G, Clin Oral Implants Res, 22 (2011) 223. doi: 10.1111/j.1600-0501.2010.02035.x. - 24. KRANJCIC J, MIKUS A, MEHULIC K, VOJVODIC D, J Prosthodont, 24 (2015) 37. doi: 10.1111/jopr.12172. — 25. KOUR N, IRSHAD N, SEHAR K, BAJJAD AA, TAGRA M, HELA AH, MISGAR AB, International Journal of Science \& Healthcare Research, 5 (2020) 242. - 26. MOUSLY HA, BADEEB BJ, BAHBISHI NA, MZAIN WM, NAGUIB GH, HAMED MT, J Orthod Sci, 12 (2020) 5. doi: 10.4103/jos.jos_74_19. - 27. TANDRA DAS T, ANAND SELVARAJ, Ijsdr, 6 (2021). - 28. PRADHAN S, MARKAM HS, CHOKOTIYA H, J Adv Med Dent Scie Res, 6/11 (2018) 110. doi: 10.21276/ jamdsr. - 29. ALSHAMMARI MS, ALSHAMMARI AS, SIDDIQUI AA, MIRZA AJ, MIAN RI, J Contemp Dent Pract, 19/1 (2018) 86. doi: 10.5005/ jp-journals-10024-2216. - 30. KASHBOUR WA, ROUSSEAU NS, THOMASON JM, ELLIS JS, Clin Oral Implants Res, 29 (2018) 309. doi: 10.1111/clr.13118. - 31. KOHLI S, BHATIA S, KAUR A, RATHAKRISHNAN T, Indian J Dent, 6 (2015) 167. doi: 10.4103/0975-962x.168518. — 32. SIDDIQUE EA, BHAT PR, KULKARNI SS, TRASAD VA, THAKUR SL, J Indian Soc Periodontol, 23 (2019) 58. doi: 10.4103/jisp.jisp_281_18.

\section{Matijević}

Faculty of Dental Medicine and Health, Josip Juraj Strossmayer University of Osijek, Cara Hadrijana 10E, 31000 Osijek, Croatia

e-mail: marko.matijevic@fdmz.hr 
ZNANJE I STAVOVI PACIJENATA O DENTALNIM IMPLANTATIMA KAO MOGUĆNOSTI LIJEČENJA NAKON EKSTRAKCIJE ZUBA

\section{S A Ž E T A K}

Cilj istraživanja je ispitati znanje i stavove pacijenata o dentalnim implantatima kao terapijskoj mogućnosti nakon ekstrakcije zuba te ispitati izvore informiranja pacijenta o dentalnim implantatima i utvrditi koje su najčešce barijere u donošenju odluke za takvu vrstu terapije. U presječno istraživanje je bilo uključeno 130 pacijenata. Radi provedbe istraživanja korišten je anonimni anketni upitnik. Anketni upitnik sastoji se od ukupno 17 pitanja s višestrukim odgovorima. Ispitanici su pokazali dobro znanje o dentalnim implantatima s iznimkom znanja o trajanju dentalnog implantata gdje su ispitanici većinom navodili kako dentalni implantat traje doživotno. Najvećem broju ispitanika, stomatolog je glavni izvor informacija vezanih za dentalne implantate. Troškovi postupka većini ispitanika predstavljaju glavnu barijeru pri odluci o ugradnji dentalnog implantata, ali ih većina želi znati više o dentalnim implantatima. Statistički značajne razlike uočene su kod znanja pacijenata u odnosu na dob i stupanj obrazovanja te kod stavova pacijenata $u$ odnosu na spol, dob i stupanj obrazovanja. 
